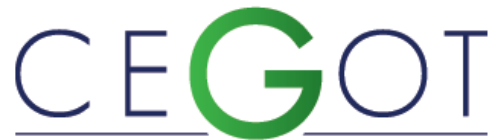

Centro de Estudos de Geografia e Ordenamento do Território
Geografia e Ordenamento do Território, Revista Eletrónica Centro de Estudos de Geografia e Ordenamento do Território http://cegot.org

CAMARA, INARA

Universidade de Lisboa, Faculdade de Arquitetura - PhD Study in Urbanism / Universidade do Oeste de Santa Catarina, Faculdade de Arquitetura, Docente em Arquitetura e Urbanismo Rua Arlindo de Mattos, 306/01 - Cep:89560-158, Videira/SC - Brasil inara.pagnussat@hotmail.com

Moscarelli, Fernanda

UniRitter - Laureate International, Programa de Pós-Graduação em Arq. e Urbanismo

Cep:90150-101, Porto Alegre/RS - Brasil

fer moscarelli@yahoo.com.br

\title{
Análise da paisagem e percepção pelos usuários do Parque da Gare, RS
}

Analysis of the landscape and perception by the users of the Park og de gare/PF

Referência: Camara, Inara; Moscarelli, Fernanda (2019). Análise da paisagem e percepção pelos usuários do Parque da Gare, RS. Revista de Geografia e Ordenamento do Território (GOT), n. ${ }^{\circ} 16$ (março). Centro de Estudos de Geografia e Ordenamento do Território, p. 29-52, dx.doi.org/10.17127/got/2019.16.002

\section{RESUMO}

A qualidade da paisagem urbana é aferida por um arranjo de elementos de infra-estrutura, mas também pela percepção das pessoas frente as funções, dimensões e elementos que configuram o espaço. Neste estudo, a análise da percepção é aferida pela identificação dos elementos que são entendidos pelos usuários como significativos para a qualidade da paisagem do Parque da Gare (Passo Fundo - RS) e quais experiências são sentidas ao longo de percursos pré-definidos pelas autoras. Este percursos foram estruturados segundo as ferramentas sugeridas por Gehl e Svarre (2013), Lynch (2012) e Cullen (2006). Ao final dos percursos, entrevistas não estruturadas foram feitas a 45 voluntários. Os resultados apontaram preferências por áreas com predomínio natural (água e massa verde), sensação de segurança e elementos de identifição histórico-cultural, como os preferidos para uso.

Palavras-chave: Espaços públicos, percepção paisagem, paisagem urbana, parques urbanos.

\section{ABSTRACT}

The quality of the urban landscape is measured by an arrangement of elements of infrastructure, but also by the perception of the people in front of the functions, dimensions and elements that set the space. In this study, the analysis of the perception is measured by the identification of the elements that are understood by users as significant to the quality of the landscape of the park of the Gare (Passo Fund - RS) and which experiences are felt along the paths Pre-defined by the authors. This pathways were structured according to the tools suggested by Gehl and Svarre (2013), Lynch (2012) and Cullen (2006). At the end of the unstructured interviews were done to the 45 volunteers. The results pointed to preferences 
by areas with natural predominance (water and green mass), sense of security and elements of historical-cultural identification, such as those preferred for use.

Keywords: Public spaces, landscape perception, urban landscape, urban parks.

\section{Introdução}

A paisagem urbana sofre transformações constantes, advindas da dinâmica das cidades de produção e transformação dos espaços. Compreender essa dinâmica e seus resultados, emerge da necessidade de compreender a cidade e seus habitantes, e ainda, o resultado destas transformações (positivos ou negativos) visando a construção de espaços mais sustentáveis, equitativos e impactantes na qualidade de vida cidadã.

Combinados com os elementos naturais, com a ecologia e com a origem social (HARDT, 2000; GRIMM E REDMAN, 2004), os processos de produção do espaço e as funções que estes locais oferecem tornam-se um somatório de elementos importantes para obter resultados projetuais mais precisos, principalmente junto às paisagens culturais, ou as quais sofreram ação e transformação humana.

No contexto da organização espacial das cidades, os locais com predominância verde, em especial os parques, são considerados elementos importantes na malha urbana por sua relação entre paisagem e memória (CERTEAU, 1996; HAESBAERT, 2007; HALBWACHS, 2006; POLLACK, 1992). Afinal, estas paisagens não são constituídas apenas de elementos naturais, mas da percepção dos indivíduos, da afetividade com o lugar e da memorialidade que este adquire através das transformações nas relações entre espaço e tempo (AMORIN FILHO, 1999; MACHADO, 1993; ROCHA, 2003; COSTA et al., 2011; RYAN, 2005).

Deste modo, fica claro que a paisagem é tomada pelo indivíduo. Luchiari (2001) afirma que "paisagem é forma e aparência. Seu verdadeiro conteúdo só se revela por meio das funções sociais que lhe são constantemente atribuídas no desenrolar da história" (LUCHIARI In: CORRÊA e ROSENDAHL, 2001, p.13). Sendo assim, toda vez que um contexto material ou imaterial altera a paisagem, acaba por introduzir nela novas funções, objetos e até mesmo valores. 
Assim, o ambiente físico e social, é aferido pelo arranjo entre dimensões relativas às características físicas deste espaço e do ambiente construído onde cada espaço é confinado (ALBERTI, 2005; COOPER et al., 2014): escala, inserção na malha urbana (e as características desta malha tais como densidade, uso), infraestrutura e acessibilidade, elementos específicos à geografia do sítio; assim como, elementos que interpelam as sensações e que se conectam com experiências pessoais ou culturais de cada indivíduo (COSTA et al., 2011; RYAN, 2005; CULLEN, 2006). Acreditamos que tanto uma quanto outra dimensão não são apreendidas sem fazer uso do julgamento do observador, do usuário ou do pesquisador.

O presente artigo, parte da perspectiva que tais elementos combinados, possibilitam estabelecer sentido entre o espaço natural, a paisagem construída e a memória coletiva urbana. A partir de uma leitura bibliográfica, entendemos que a melhoria da qualidade de vida urbana, exige avanços na construção de critérios multidisciplinares capazes de medir a qualidade dos espaços urbanos (VAN KAMP et al., 2003). Tal análise é primordial à fim de se estabelecer parâmetros que possam ser incorporados nas políticas de planejamento urbano e espacial.

Tratando-se do escopo deste trabalho, uma pesquisa que pretende identificar a percepção e apropriação dos usuários do Parque da Gare (Passo Fundo - RS) após sua reestruturação física, o foco volta-se para a análise qualitativa de elementos constituintes no parque, percebidos pelos usuários como geradores de afetividade, imagem, memória e identificação e seu impacto na atratividade do Parque como espaço livre. É imprescindível conhecer estes elementos para o planejamento das cidades, uma vez que as paisagens irão influenciar a qualidade de vida de forma particular em cada local.

\section{Paisagem e percepção}

A origem da palavra paisagem está ligada a diferentes conceitos. Pode se referir ao conceito de território, ou relacionada ao espaço geográfico. Na Geografia este termo vem sendo discutido desde o século XIX, principalmente visando entender o produto fisionômico das relações sociais e naturais de um determinado espaço e sua dinâmica (SCHIER, 2003). 
Nas últimas décadas, foram realizadas tentativas de reestabelecer visões mais integradas da paisagem, através de novas abordagens e métodos. Berque (1994) afirma que a paisagem reside não somente no objeto (o meio ambiente, espaço ou suporte físico) nem somente no sujeito (a ação humana), mas na complexa interação entre ambos.

Claval (2004) complementa considerando a paisagem como resultado de uma subjetividade decorrente, entre outros fatores, do olhar humano sobre o meio ambiente. Deste modo

A percepção surge como um fator fundamental na formação das paisagens, pois estas se revelam diferentemente a cada observador. A percepção é um fator fundamental para a avaliação da relação do homem com o espaço onde ele vive e como ele visualiza o mundo externo. O estudo da percepção vem auxiliando na compreensão da relação homem/natureza, homem/ambiente construído, no processo de gestão e planejamento participativo em diversos lugares. (MELO et al., 2017, p.110)

Machado (1993) e Rocha (2003) estudaram a percepção dos espaços urbanos como um campo que pode determinar sentimentos, ideias, imaginário, necessidades, expectativas e interpretação da sociedade sobre a realidade dos fatos cotidianos e as relações que a envolvem. De modo geral, as cidades se tornam agradáveis quando criam contato com a natureza, com a massa vegetal e com a diversidade de usos, identificada nos parques, por exemplo.

No caso dos parques, definidos como espaços livres públicos urbanos, com dimensões significativas e predominância de elementos naturais, destinados à recreação da massa e capazes de incorporar intenções de conservação (KLIASS, 1993; GONÇALVEZ, 1994; MACEDO E SAKATA, 2003), se, adequadamente conservados, proporcionam satisfação física e psicológica, lugares ${ }^{2}$ de lazer na malha urbana, sociabilização, redução do stress e valorização estética (TARDIN, 2008; BARGOS E MATIAS, 2011; GALENDER, 1992, 2005; CHIESURA, 2004; CVEJIĆ et al. 2015; TZOULAS et al., 2007; ALBERTI, 2005).

Ainda, a percepção dos indivíduos com os lugares, possibilitam entender a ideia da paisagem urbana como categoria descritiva, mas também enquanto discurso da imagem, construindo-se e sendo constitutiva da memória, cujos limites cognitivos são orientados pela experiência (MELO et al., 2017, p.112). Neste sentido, passa a romper sua conceituação

\footnotetext{
2 Segundo Marc Augé, (AUGÉ, 1994 apud SÁ, 2014), o termo "lugar" ou "lugares" expressa a ideia de espaços símbólicos. Os "lugares antropológicos" seriam assim denominados pelas relações de sociabilidade (AUGÉ, 1994 apud SÁ, 2014). De forma oposta, a ideia de "não lugares" (ou espaço) transforma o ator social em espectadores de um lugar profundamente codificado, do qual ninguém faz verdadeiramente parte.
} 
somente geomorfológica, mas como aspecto cultural, em virtude dos processos de construção homem/natureza e da relação entre espaço/tempo.

Este processo, segundo Oliveira (1983), constitui-se de fases distintas do qual a percepção faz parte (sensorial), assim como a seleção (memória), e pôr fim a atribuição de significados (raciocínio).

Dentre os meios pelos quais os seres humanos respondem ao meio ambiente, destacamos o conceito de "topofilia", criado por Tuan (1980), que representa os elos afetivos que os indivíduos constrõem em relação a um determinado lugar ou ambiente físico. Segundo o autor

A palavra "topofilia" é um neologismo, útil quando pode ser definida em sentido amplo, incluindo todos os laços afetivos dos seres humanos com o meio ambiente material. Estes diferem profundamente em intensidade, sutileza e modo de expressão. A resposta ao meio ambiente pode ser basicamente estética: em seguida, pode variar do efêmero prazer que se tem de uma vista, até a sensação de beleza, igualmente fugaz, mas muito mais intensa, que é subitamente revelado. A resposta pode ser tátil: o deleite ao sentir o ar, água, terra. Mais permanentes e mais difíceis de expressar, são os sentimentos que temos para com um lugar, por ser o lar, o locus de reminiscências e o meio de se ganhar a vida. (TUAN, 1980, p.107)

$\mathrm{Na}$ vida moderna e agitada das cidades, falta às pessoas o contato com o meio ambiente natural. Essa relação, é ainda mais percebida pelas crianças que sabem relativamente pouco sobre como perceber o playground, o parque, o sossego dos lugares. Tuan (1980) relaciona a topofilia também à criança, onde a natureza produz sensações deleitáveis e indiferença pelas regras de beleza definidas. Para o autor, "um ambiente como este pode romper todas as regras formais de euforia e estética, substituindo a confusão pela ordem e no entanto, ser completamente desfrutável" (ibid., p.111).

O Parque da Gare, como citado no item 3, além da presença de grande massa verde, possui características histórias fortes, que remetem ao patriotismo ${ }^{3}$ dos Passofundenses. Essa "consciência do passado é um elemento importante no amor pelo lugar. A retórica patriótica sempre tem dado ênfase às raízes de um povo. Para intensificar a lealdade se torna a história visível com monumentos na paisagem e as batalhas passadas são lembradas" (ibid., p. 114).

\footnotetext{
${ }^{3}$ Para Tuan (1980, p. 115) “o patriotismo significa amor pela terra pátria ou terra natal.
} 
Essa característica patriótica, é o elo topofílico em relação ao senso de lugar dos povos. Tuan (ibid., p. 116) afirma que "para o indivíduo, a sua realidade depende da aquisição de certos tipos de conhecimento". Desde modo, para estes indivíduos, o respeito e honra que possuem com seu lugar de origem, aponta os laços da natureza ou da sua história como definidores de amor pela sua terra.

Nesta perspectiva, as formas sociais e econômicas contribuem de forma extraordinária na definição de estilo de vida e dos espaços (padrões espaciais) que geram as sensações topofílicas. Nas cidades atuais, os ambientes que geram bem-estar a um indivíduo ou população, incluindo suas atitudes em relação ao lugar, somente pode ser vista e descrita através de evidências diárias e do caráter das circunstâncias físicas onde ocorrem.

Deste modo, nesta pesquisa, é através da paisagem urbana e do ambiente (re) construído que acontecimentos são percebidos e geram emoções e símbolos para um local definido: o Parque da Gare. Estudar e conhecer essas sensações topofílicas é importante para nortear futuros projetos ou mesmo manter a atratividade do Parque como um elemento de socialização, lazer e qualidade de vida. Sabemos que, em muitos casos os projetos são pensados apenas baseado na percepção e experiência do corpo técnico que o produz, não considerando o usuário e visitante como agente na transformação.

\section{Passo Fundo e o Parque da Gare}

A cidade de Passo Fundo, localizada no norte do Rio Grande do Sul, Brasil; é considerada uma cidade média, contando com população estimada de 199.799 habitantes (IBGE, 2017). $\mathrm{Na}$ área urbana de Passo Fundo existem trinta e uma praças e apenas dois parques: $\mathrm{O}$ Parque da Vergueiro e o Parque da Gare, revitalizado em 2016, que pertence a ZRT66 (Zona de Recreação e Turismo) do Plano Diretor Municipal de 2006.

\footnotetext{
${ }^{4} \mathrm{O}$ setor possui população de aproximadamente 21.942 mil habitantes (IGBE, 2016).
} 


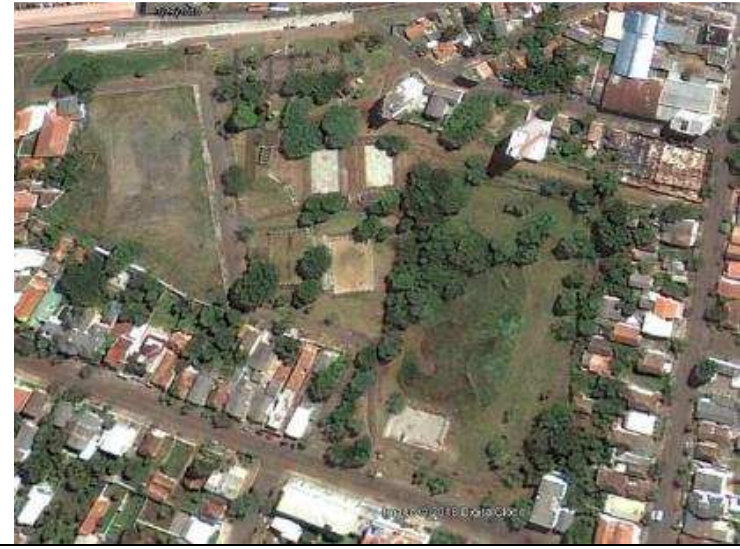

Figura 1- Imagem Parque em meados de 2010. Fonte: Google Earth, $2018^{5}$.

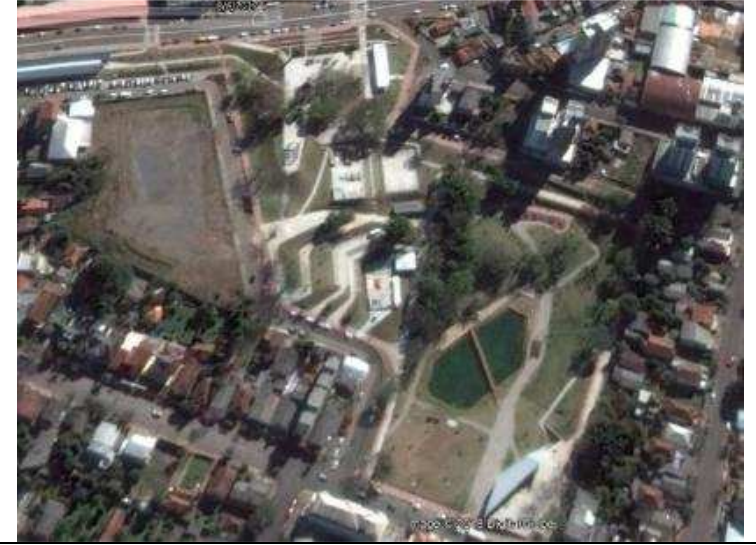

Figura 2 - Imagem atual do Parque.

Fonte: Google Earth, 2018.

Com área de 72 mil m$^{2}$ (PMPF, 2016) $)^{6}$ o Parque da Gare está inserido na malha urbana de Passo Fundo e é circundado por grande diversidade de usos e ocupações do solo. A figura 3 apresenta a relação entre estes usos e sua proximidade com o Parque, com destaque para a antiga Estação Ferroviária e serviços institucionais.

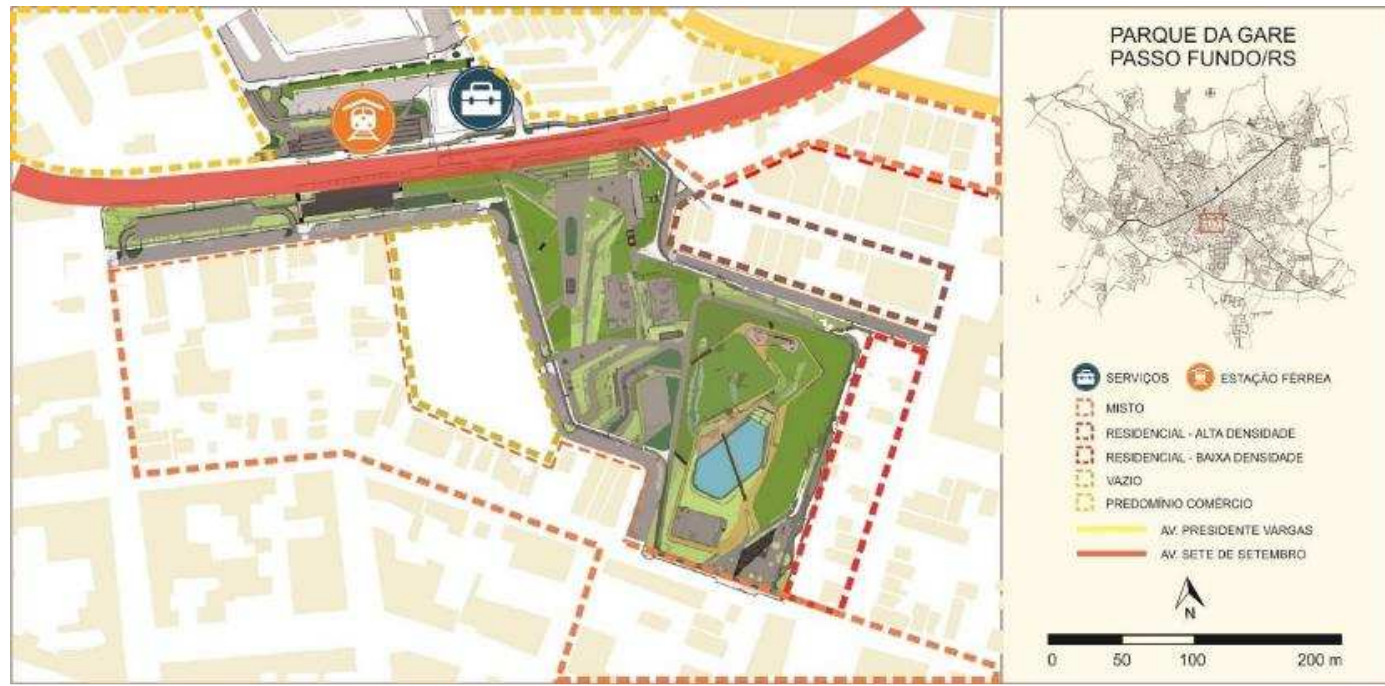

Figura 3 - Localização do Parque da Gare e predominância de usos no seu entorno. Fonte: autoras, (2017) sobre base AUTOCAD.

\footnotetext{
${ }^{5}$ Esta imagem foi captada em 2010 pelo Google Street View, porém, seu acesso e salvamento foi realizado em 2018.

${ }^{6}$ Esta área inclui a estação férrea, revitalizada em 2016 e parte integrante do conjunto histórico da Gare. 0 território correspondente ao parque possui 5 ha.
} 
A figura 4 está relacionada no mapa (figura 3) e corresponde a antiga Estação Férrea, desativada em meados dos anos de 1980; a figura 5 corresponde à atividades institucionais(Senac e Hemopasso) e; as figuras 6 e 7 a morfologia das edificações de comércios e residências mistas que fazem interface entre a Gare e o bairro Nicolau Vergueiro.

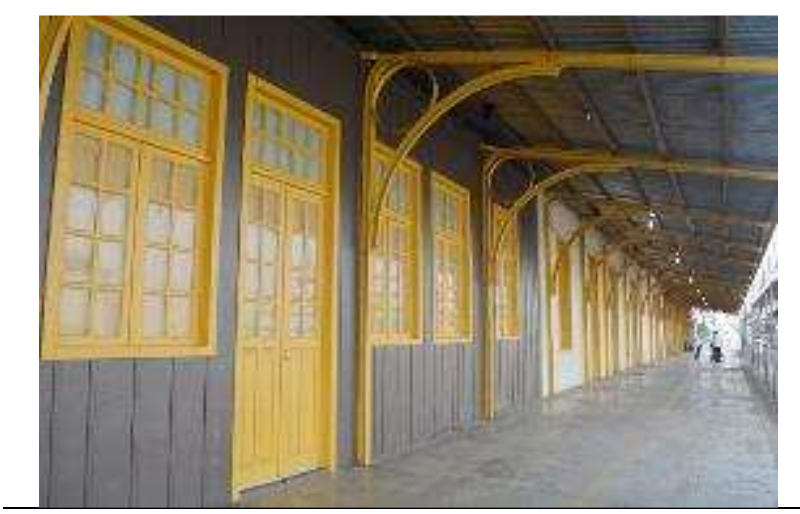

Figura 4 - Estação Férrea, após a revitalização em 2016. Fonte: Jornal Online Diário da Manhã, 2017

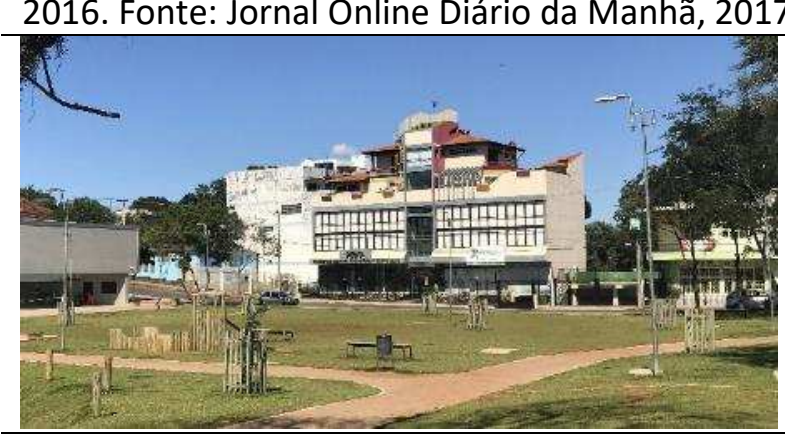

Figura 6 - Unidades mistas, comercial - Rua Minas Gerais. Fonte: autoras, abril de 2018

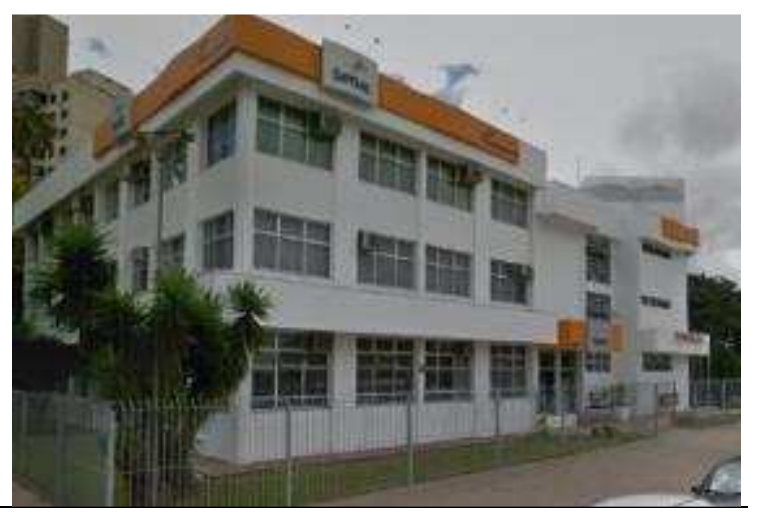

Figura 5 - Senac - vista principal-, e ao fundo Hemopasso. Fonte: autoras, abril de 2017

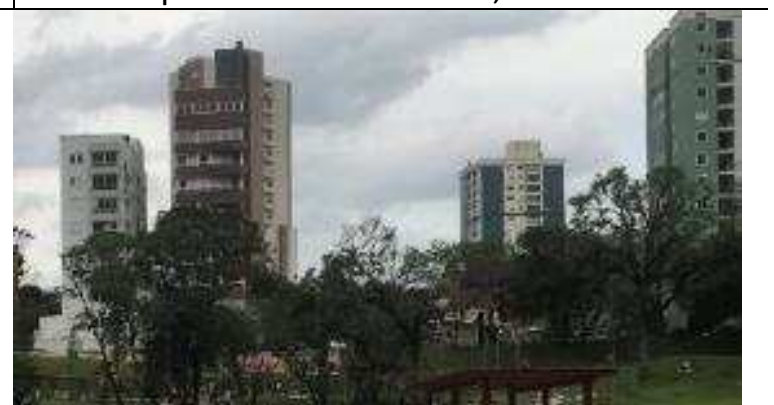

Figura 7 - Área mais densa, residenciais - Rua TV do Parque. Fonte: autoras, junho de 2017

\section{Método}

A proposta metodológica é de abordagem qualitativa e, seus resultados dependem muito de como os usuários percebem o lugar. Esta pesquisa, que é parte de um estudo mais vasto, não objetiva a representatividade numérica, mas, a compreensão de elementos e sensações importantes através das informações coletadas (GERHARDT e SILVEIRA, 2009). Através de percursos pré-definidos pelas autoras, 45 usuários ${ }^{7}$ percorrem os trajetos, conforme métodos descritos abaixo. Estes percursos objetivam caracterizar a qualidade do Parque, as

\footnotetext{
${ }^{7} \mathrm{O}$ resultado no número de voluntários foi reflexo das pessoas que se dispuseram em contribuir com a pesquisa, realizando os percursos e métodos solicitados pela autora.
} 
experiências sentidas (afetividade, imagem, memória, identificação) e os elementos vistos como importantes pelos usuários.

Os métodos utilizados tiveram embasamento inicial em Whyte (1977) e Sartori (2000), que sugerem o triangulo metodológico formado pela tríade (1) observando, (2) perguntando e ouvindo e (3) registrando. Para reforçar esses métodos, as análises perceptivas também partiram dos princípios e técnicas qualitativas de compreensão da vida pública adotados por Cullen (2006) com a análise de percursos (visão óptica, visão local e conteúdo); por Lynch (2012) através da análise de dimensões (vitalidade, sentido, adequação, acessos e controle) e por Gehl e Svarre (2013), os quais envolvem a contagem, mapeamento, rastreamento, sombreamento, traços, imagens, diários e passeios teste. Nesse sentido, foram identificados trajetos mais atrativos aos usuários.

Os percursos de 1 a 5 foram observados, no primeiro momento, por 35 pessoas de diferentes faixas etárias e gênero. Como o objetivo era relatar elementos de infraestrutura vistos como importantes e percepções dos percursos, alguns dos voluntários não foram identificados ${ }^{8}$. Eles receberam um mapa com os percursos e através de trocas de e-mails, anotações ao longo dos percursos, e por aplicativo whatsapp relataram suas vivências. Deste modo os autores puderam manter um diário com as informações.

A partir dos resultados do estudo piloto, identificamos a necessidade de dois percursos adicionais, estes foram feitos por 10 pessoas. Deste modo, os percursos 1 a 5 (piloto) foram feitos por 45 voluntários e os percursos 6 e 7 somente por 10 voluntários. Entendemos que a quantidade e variabilidade de observadores atende ao objetivo proposto, visto a dimensão do Parque e o aprofundamento deste ítem no estudo proposto. A seguir apresentam-se os percursos finais pré-definidos pelos autores e realizados pelos usuários.

\footnotetext{
${ }^{8}$ Tivemos dificuldade em conseguir voluntários, visto que são diversos percursos e necessitamos de disposição e dedicação dos voluntários para troca de mensagens e compartilhamento de levantamento fotográfico.
} 


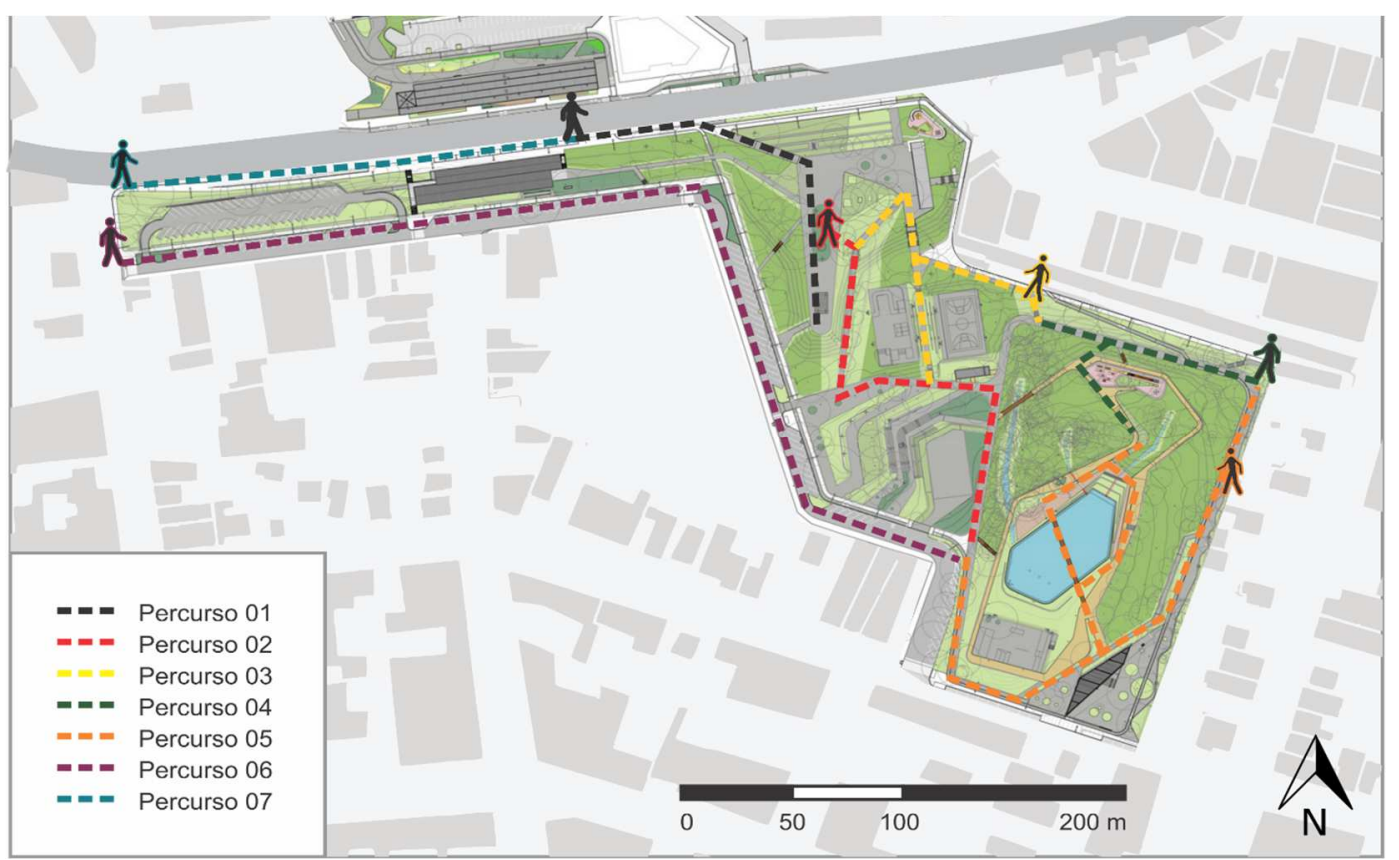

Figura 8 - Percursos definidos após piloto.

Fonte: A autora, maio de 2018.

Fechadas as observações, entrevistas não estruturadas foram realizadas, onde os usuários mostram as fotos e relatam o que viram, sentiram, os pontos positivos e negativos. Com o uso de um smarphone, as entrevistas foram gravadas para posteriormente serem compiladas e estruturadas nas tabelas apresentadas nos resultados. Alguns usuários fotografaram os percursos e gravaram áudios, enviados via whatsapp à autora. Outros ainda, enviaram os resultados (fotos e percepções) via e-mail.

Através deste levantamento também foi possível apurar a percepção dos usuários quanto ao estado de qualidade e conservação do Parque, em relação às mesmas características existentes (ou não) antes da requalificação e vislumbrar uma perspectiva de conservação e manutenção para o futuro próximo.

\section{Apresentação dos resultados}

Os quadros abaixo representam as categorias mais analisadas que envolvem elementos observados e sensações provocadas ao voluntário durante a realização percurso. Os 
números em cada coluna são a somatória de vezes que esses elementos foram citados pelos mesmos.

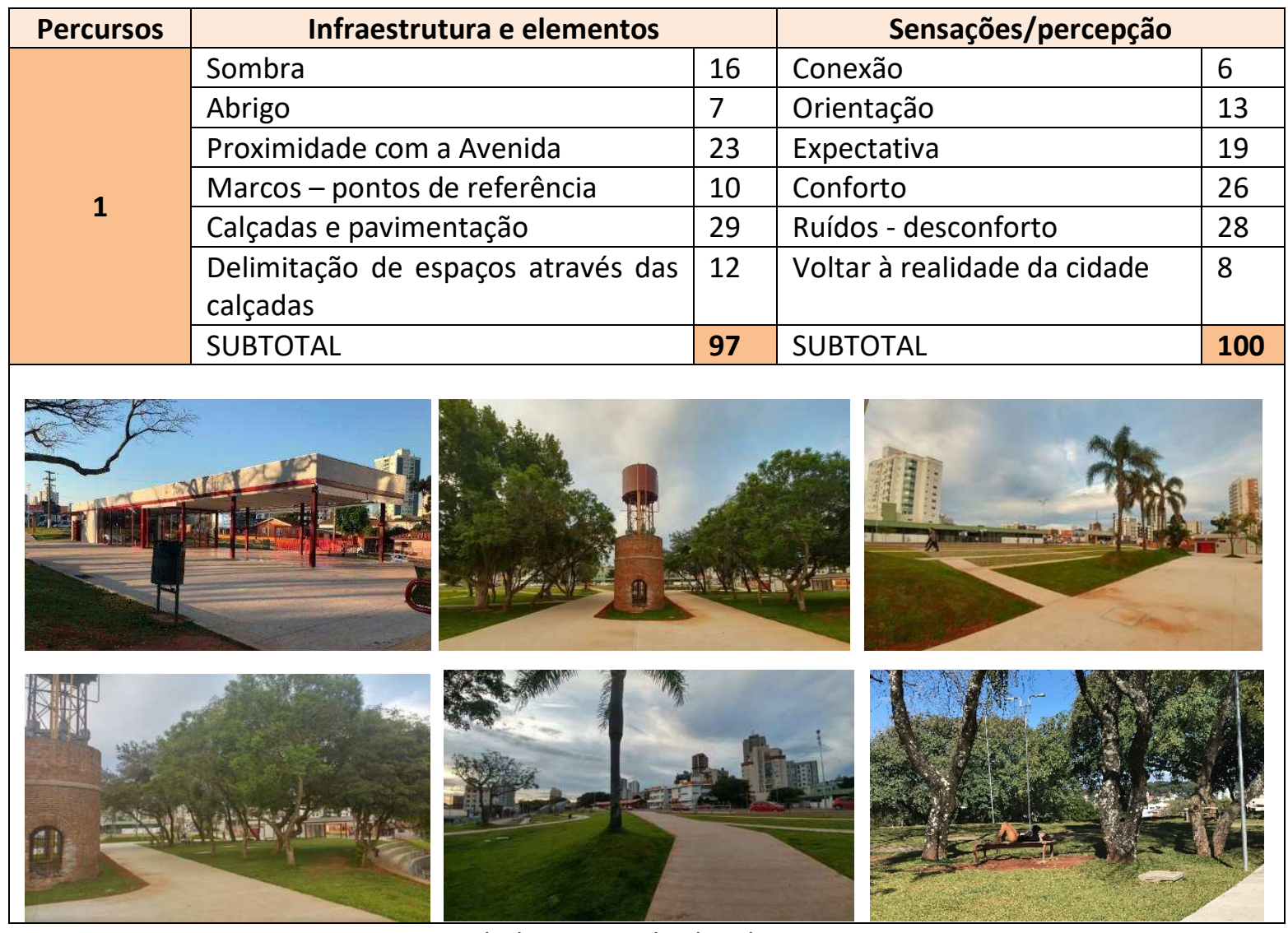

Tabela 1 - Resultados do percurso 01.

Fonte: A autora, com fotos dos voluntários, 2018.

Através dos relatos, o Percurso 01 trouxe um acontecimento surpresa: os voluntários que iniciaram por este percurso, tiveram percepções diferentes dos voluntários que o fizeram ao final dos demais percursos. Em ambos os casos, os voluntários identificaram com destaque as calçadas como sendo seguras, com boa manutenção, largura adequada sem obstrução visual e física. Esse mesmo elemento de infraestrutura foi relacionado às sensações de conforto, caminhabilidade e atratividade. Em contrapartida, o desconforto advém do ruído da avenida e da sensação de insegurança pela proximidade que ambas mantêm.

A curiosidade aqui relatada, se deu pelos usuários que não seguiram a ordem numérica e finalizaram a atividade com o percurso 01. Oito voluntários expuseram seu desconforto em relação à conexão entre parque e cidade, e a sensação de desagrado em "voltar a realidade da cidade" ${ }^{\prime \prime}$. Em segundo plano, se destacou a clareza dos caminhos e calçadas, os quais

\footnotetext{
${ }^{9}$ Esta citação foi repetida por oito voluntários, os quais fizeram o percurso 01 ao final dos demais percursos.
} 
proporcionaram ao voluntário orientação e expectativa em fazer os demais percursos. Ainda, a presença de locais sombreados e elementos identificados como "pontos de referência" 10 , os quais entendemos como marcos da paisagem, foram bastante citados e percebidos.

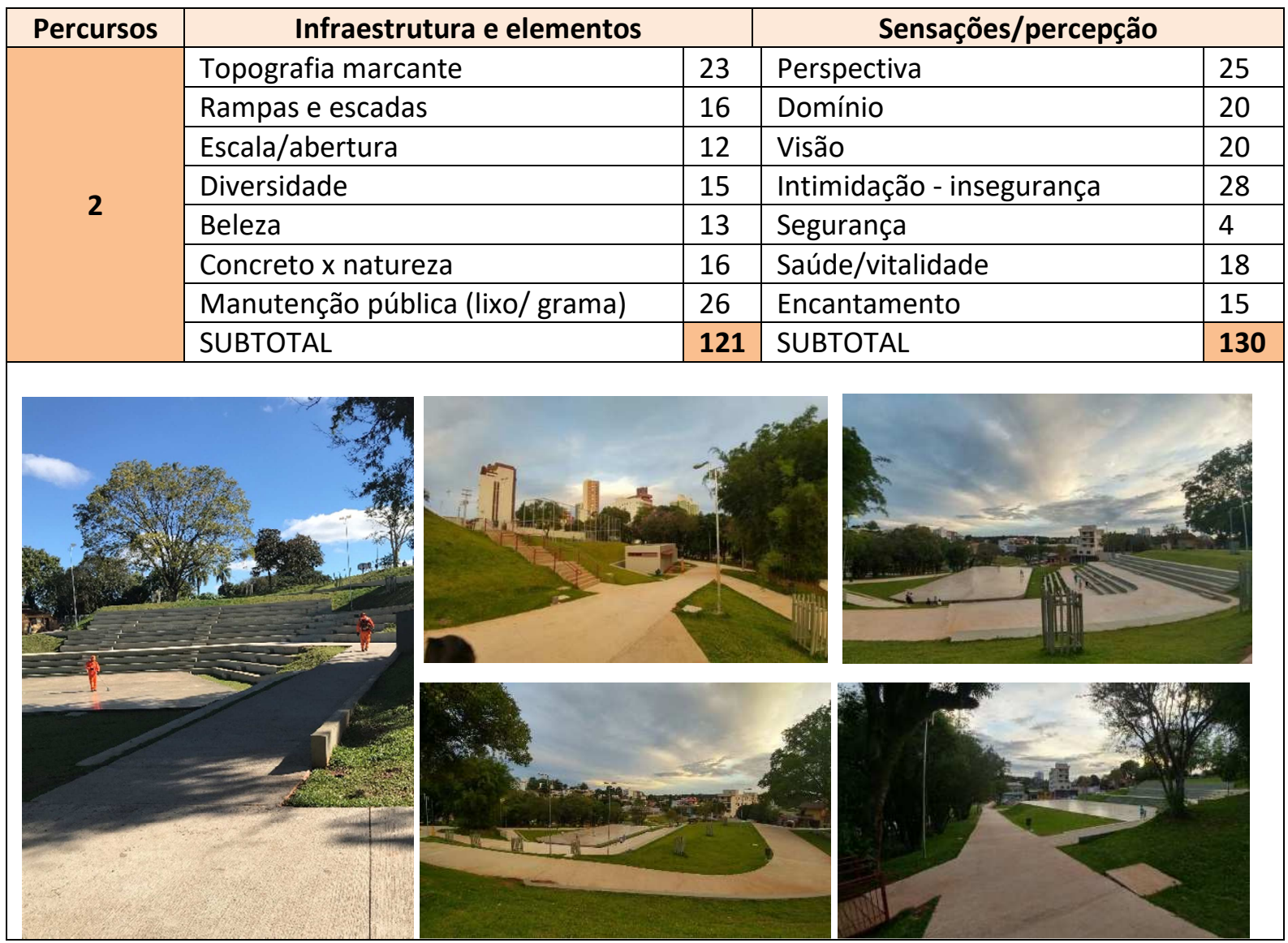

Tabela 2 - Resultados do percurso 02.

Fonte: A autora, com fotos dos voluntários, 2018.

No Percurso 02 os elementos entendidos como importante destacam a topografia acidentada e a manutenção do Parque. No ponto mais alto, os sentimentos enfatizados envolvem a amplitude e perspectiva da visão e domínio em relação ao que se vê. Conforme este percurso é feito, novos usos e ambientes vão se mostrando ao indivíduo. Ao passo que o nível fica mais baixo, embora a forma seja voltada para a escala humana, a topografia natural gerou insegurança e locais de encurralamento - a última foto acima destaca o local onde os usuários relataram com destaque, se sentir "presos" em meio a topografia.

\footnotetext{
${ }^{10}$ Termo utilizado por alguns dos voluntários.
} 
A manutenção também é percebida pelos voluntários. Este percurso possui maior amplitude visual, o qual foi destacado através da presença de grandes áreas gramadas e pavimentadas. Com isto, a limpeza e manutenção da grama ficou evidente ao observador.

Alguns voluntários destacaram a vitalidade pela presença de pessoas circulando, trabalhadores realizando a manutenção, diversidade de padrões espaciais e interfaces. Em suma, a vitalidade percebida neste local é entendida como a intensidade e riqueza de apropriação e interação do espaço público e a presença de espaços compactos (GEHL, 2011) que são capazes de proporcionar distâncias de tráfego tão curtas quanto as experiências sensoriais dos usuários.

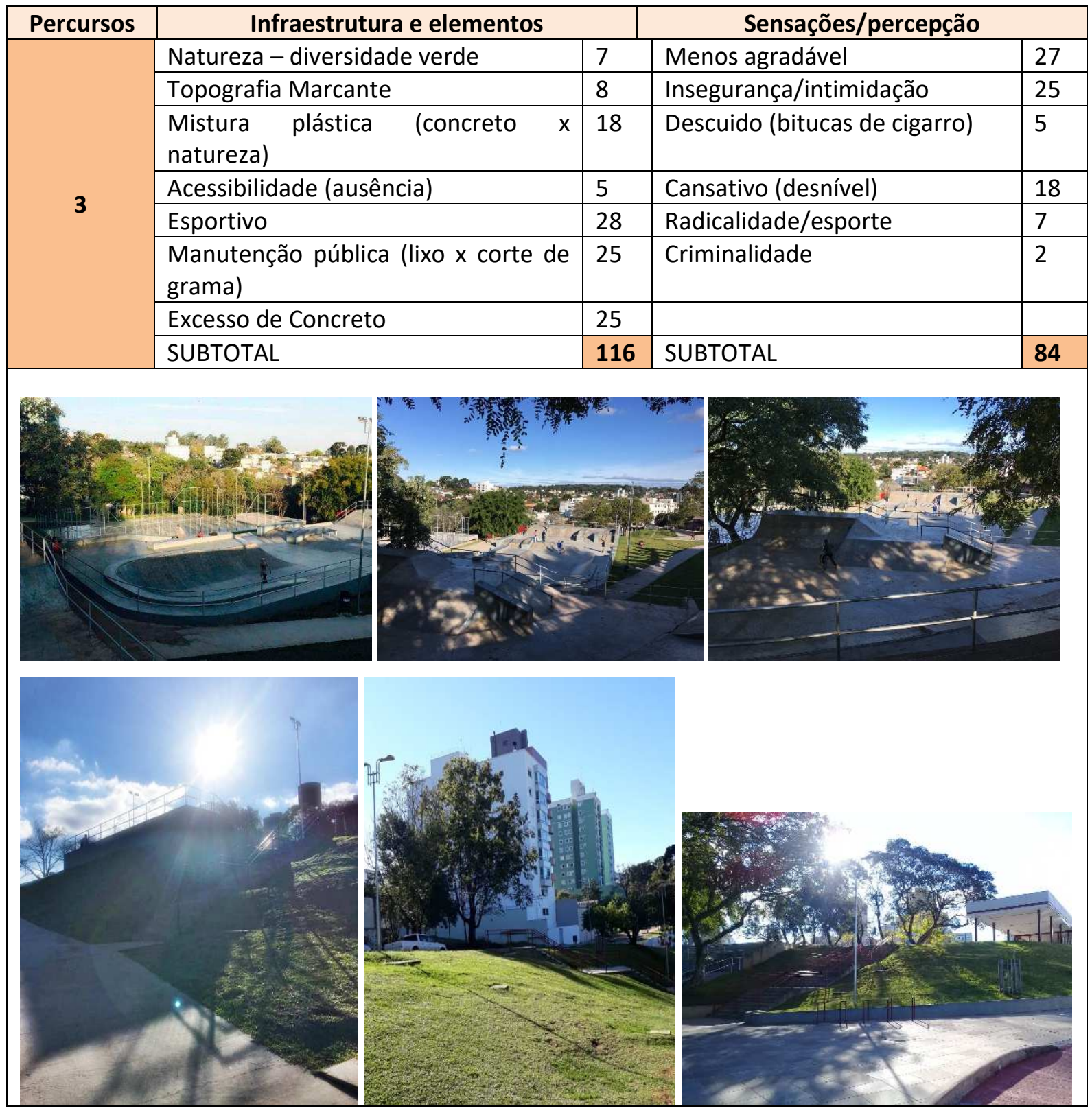

Tabela 3 - Resultados do percurso 03.

Fonte: A autora, com fotos dos voluntários, 2018. 
O excesso de concreto e menor massa verde no percurso 03 foi percebido pelos usuários como desagradável. No seu entorno, para suprimir os acessos e o desnível, existem várias escadas, as quais foram identificadas como elementos pouco acessíveis e cansativos. A presença da quadra poliesportiva e da pista de skate é citada pelos voluntários com finalidade e uso mais radical, voltados ao esporte.

Porém, embora a manutenção de modo geral tenha sido relatada como positiva, os voluntários perceberam muitas bitucas de cigarro em todo o percurso, principalmente próximo às pistas. Os relatos também apontam para uma área que gera sensação de insegurança devido às aglomerações de usuários, "grupos fechados" e com forte cheiro de Cannabis sativa ${ }^{11}$ resultando em imprevisão, insegurança e sensação de medo.

O percurso 04, está paralelo a Rua TV do Parque e possui um playground. Devido a presença da área infantil, os voluntários relatam o sentimento de diversão e sensação de felicidade pela movimentação e brincadeiras e presença de elementos lúdicos, como o uso de cores nas calçadas, formas geométricas e o próprio playground. A delimitação foi outro elemento notório. Entendemos que, é através do talude, da escadaria e de um painel colorido que os voluntários se referem a delimitação e definição de espaços, visto que, de um lado está a rua - de mão única e circulação de veículos e bicicletas-, e de outro a área do playground. Esses diferentes usos, estão claramente delimitados por cores, gramados e circulações.

\footnotetext{
${ }^{11}$ Nome científico da maconha.
} 


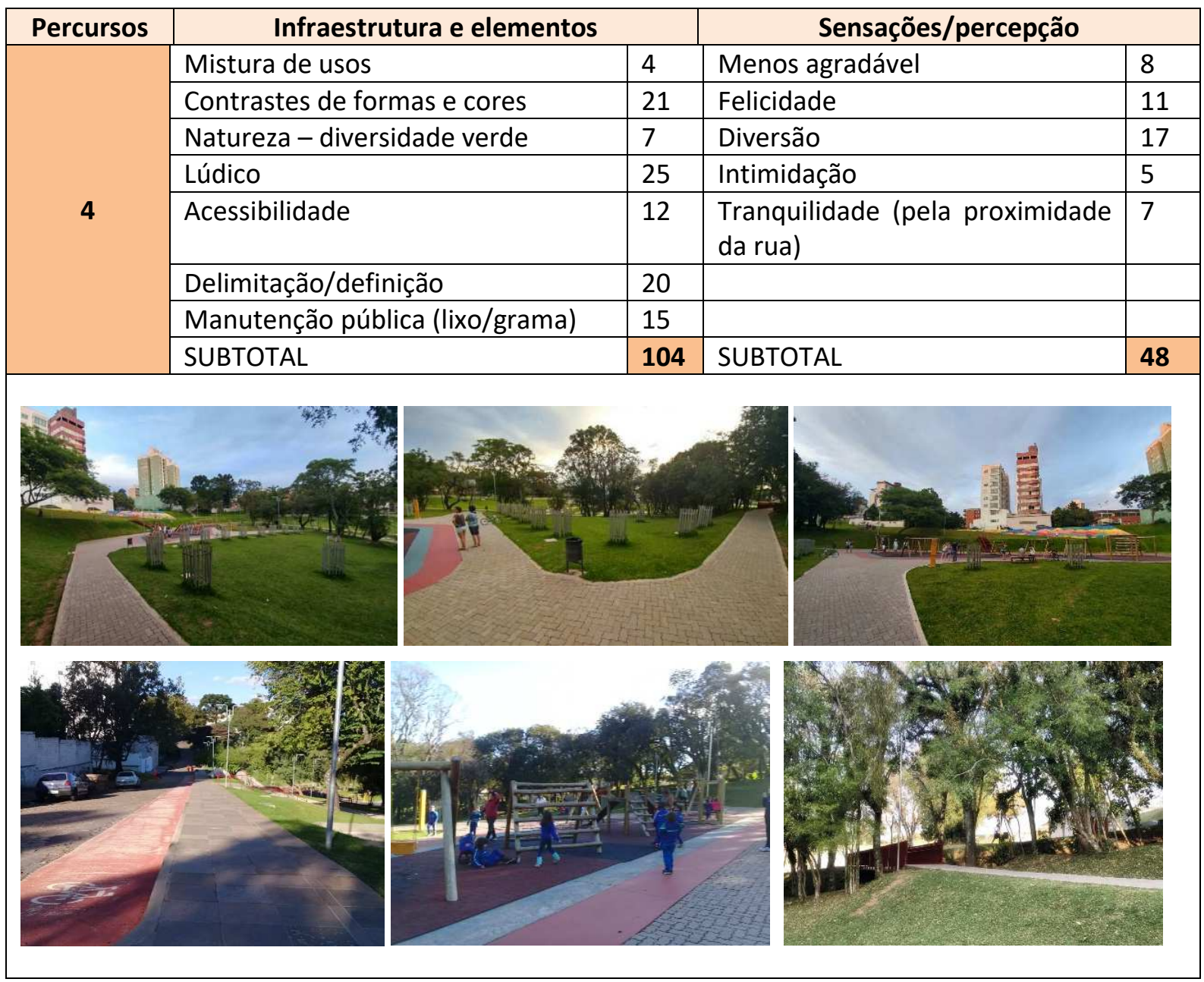

Tabela 4-Resultados do percurso 04.

Fonte: A autora, com fotos dos voluntários, 2018.

Em contrapartida a isto, os relatos de intimidação se referem a ponte que liga o percurso 4 ao percurso 2 (última imagem da tabela 4). Esta, está fechada por vegetação de copa larga, é estreita e obriga os usuários a passarem muito próximos uns dos outros gerando insegurança e potencializando possíveis assaltos.

O percurso 05 , foi o mais registrado fotograficamente e descrito pelos usuários, de forma geral. Embora seja o percurso mais longo em extensão, contornando o lago, os usuários descreveram a presença da água como um elemento de contemplação e grande beleza tanto estética quanto geometricamente. Os caminhos que o contornam, foram descritos como confortáveis, com inclinações suaves e agradáveis de circular.

A diversidade de locais para sentar, sejam sombreados ou iluminados e aquecidos pelo sol, provocaram tranquilidade e conforto e potencializam o uso em diferentes estações. Os sentimentos de surpresa e curiosidade, são resultados de um nível topográfico mais baixo - 
no contexto do Parque-, onde os voluntários foram surpreendidos, quando vindos do percurso 2 ou 7, por uma amplitude visual e sensação de liberdade.

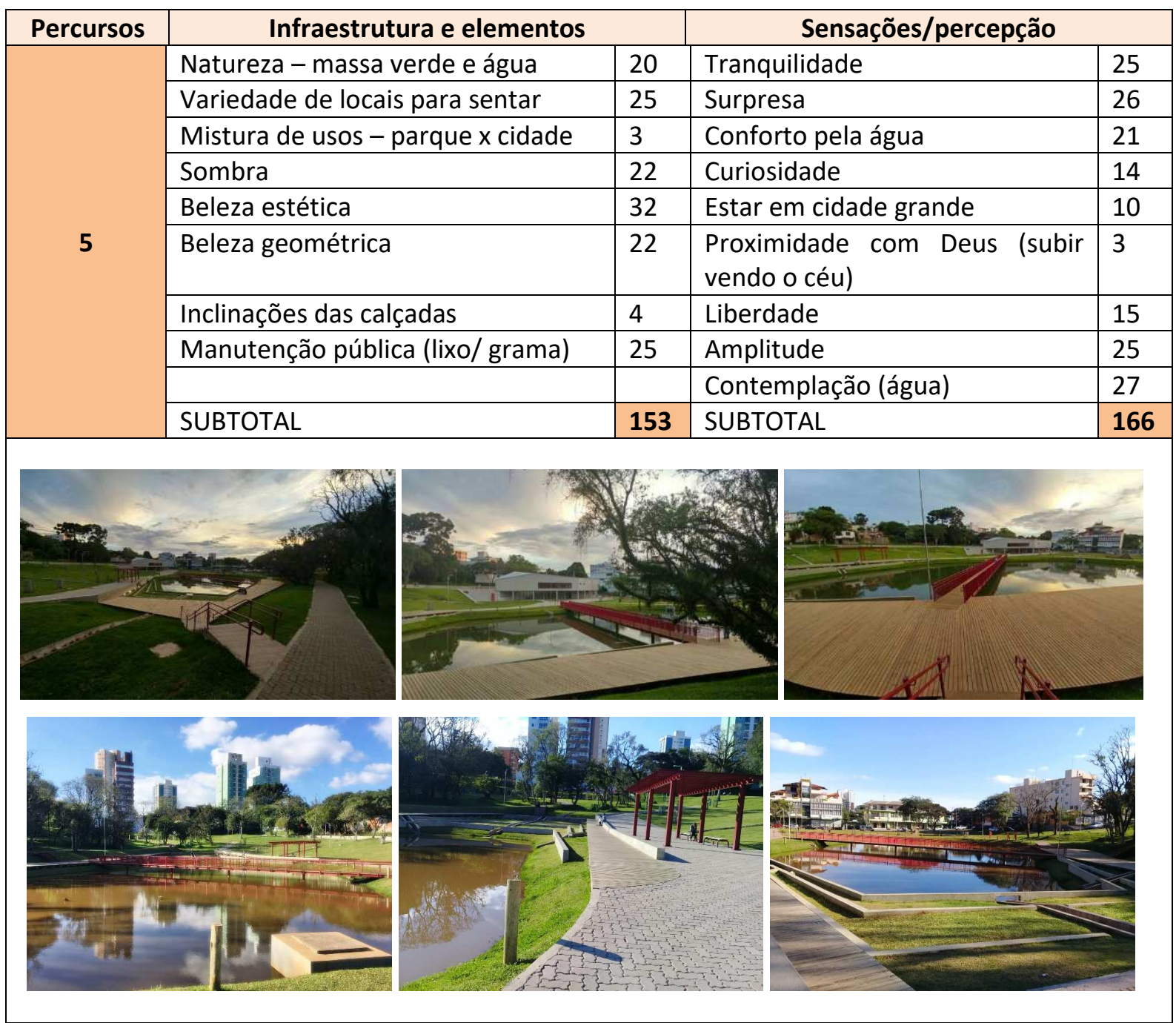

Tabela 5 - Resultados do percurso 05.

Fonte: A autora, com fotos dos voluntários, 2018.

Embora esteja próximo a uma rua movimentada - a Rua Minas Gerais - esta possui densidade mais baixa e não foi vista como barreira ou sentimento de insegurança. Entendemos que, a distância da rua e a barreira de grama que existe entre os espaços, pode ter sido elemento que assegurou segurança e tranquilidade aos voluntários. Alguns ainda relataram a sensação de estarem em cidades grandes, comparando o espaço aos Parques de Curitiba.

Conforme contornavam o percurso em direção ao percurso 4, subindo o nível topográfico, sentimentos de "proximidade com Deus" foram mencionados. Entendemos que, ao realizar 
este trajeto, o céu vai se tornando próximo, o que estimulou tal sensação. A presença da água, também é sentida como ambiente tranquilo, de relaxamento e agradabilidade.

A manutenção constante do gramado foi destacada e observada, visto que o local está bem cuidado e não há sujeira ou lixo na sua extensão. Uma vez que, as pessoas podem se observar, isso se torna vital para que se sintam responsáveis e os olhos da segurança (JACOBS, 1960) e da manutenção e higiene do espaço. Ainda, há funcionários públicos que cuidam diariamente da manutenção e limpeza do Parque.

Os voluntários também relatam, que este percurso dispõe de diversos locais para sentar: está equipado com bancos, alguns espaços são planos podendo fazer uso de cadeiras e outros são desnivelados, mas estando limpos e secos, podem se sentar no próprio gramado. Ainda, existem locais sombreados para os dias quentes e locais abertos e livres, para os dias mais frios, que são vários meses na região sul.

Embora o lago pudesse ser um elemento de insegurança para crianças menores, não houve nenhum relato que identificasse esse sentimento. Compreendemos que, sua abertura de campo visual, pode proporcionar essa tranquilidade aos pais ou responsáveis. A nova edificação, também não foi relatada pelos voluntários, uma vez que se torna em plano secundário contrapondo a beleza do local. Visto que, durante esta pesquisa ainda não estava aberta ao público, ou nenhum dos voluntários pode fazer uso de sua estrutura, passou despercebida durante as observações.

O percurso 06, foi realizado por uma quantidade significativamente menor de voluntários, mas entendemos como suficiente visto que seus relatos foram semelhantes atingindo o ponto de saturação. Os elementos percebidos neste percurso destacam para a mistura de usos, uma vez que é um percurso onde, de um lado está o Parque e de outro lado a diversidade morfológica da cidade.

A presença da nova edificação, destinada à Feira do Produtor Rural, foi elemento que conferiu o título de futurismo pelos convidados. Entendemos que, isso se deve ao fato de ser construída em estrutura metálica, com geometrias destacadas em cor vermelha e com um formato geométrico não convencional da arquitetura local. 
As calçadas foram vistas como insuficientes e estreitas, impossibilitando grandes circulações de pedestres. Em parte do percurso, a ausência de árvores de porte e copas grandes, que proporcionam sombreamento também foram sentidas. Alguns usuários relataram insegurança e desarmonia pela presença de terrenos vazios, sem uso efetivo do solo, que poderiam potencializar a criminalidade ou a proliferação de mato, bichos e afins. Ainda, houveram relatos sobre o desconforto dos ruídos ocasionados por carros e ônibus que trafegam pela Avenida Sete de Setembro.

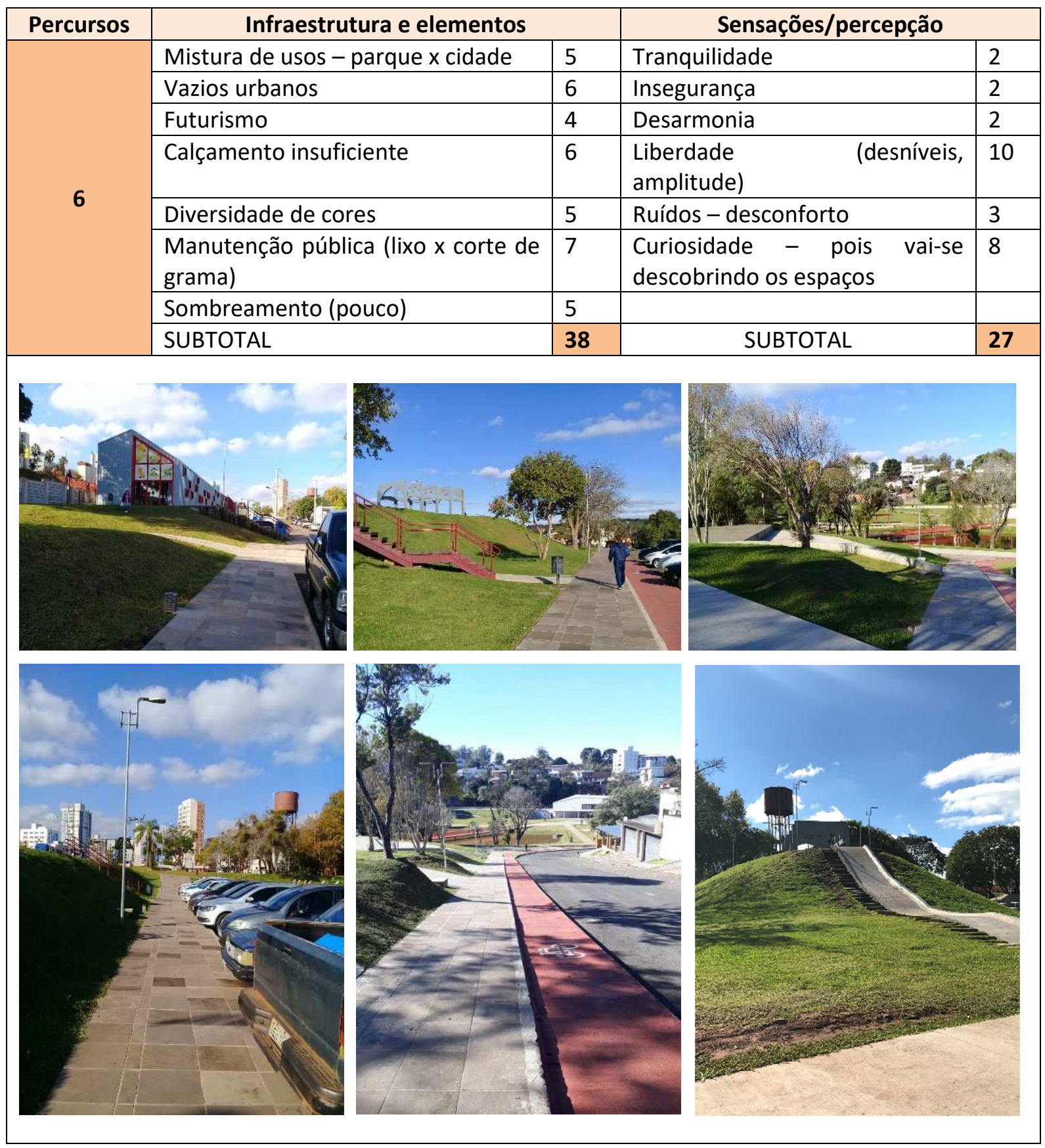

Tabela 6 - Resultados do percurso 06.

Fonte: A autora, com fotos dos voluntários, 2018. 
Neste percurso, nos surpreendemos com a descrição de sensação de liberdade, relatada por todos os voluntários. Alguns a descreveram devido a topografia e outros à amplitude visual do local, que permite ir descobrindo novidades no decorrer do percurso, tanto no âmbito do Parque, quanto na morfologia da cidade.

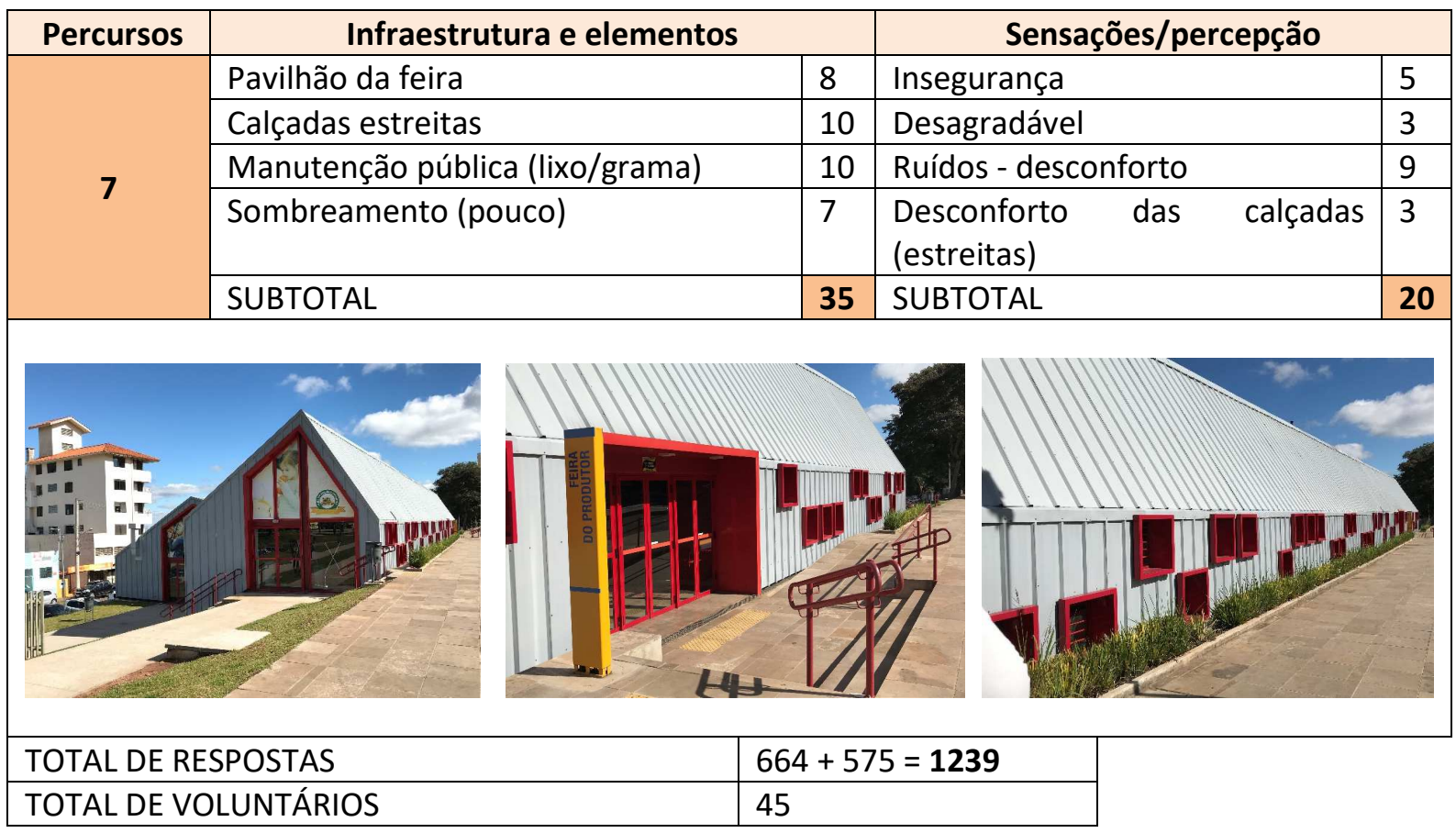

Tabela 7 - Resultados do percurso 07 e somatório de respostas de todos os percursos.

Fonte: A autora, com fotos dos voluntários, 2018.

O percurso 07, mostrado acima, teve como elemento destaque o pavilhão da feira; as calçadas muito próximas à Avenida e estreitas - visto que é local de passagem e maior circulação de pedestres-; a manutenção eficiente da limpeza urbana e a ausência de vegetação de sombra, tornando o trajeto desagradável em dias quentes e ensolarados.

Devido à ausência destes elementos, as sensações foram de desconforto na circulação, nos ruídos e insegurança. A Avenida possui grande circulação de veículos motorizados, transporte coletivo, o que acarreta em barulho e poluição, sentidas pelos voluntários. Entendemos que, os que expuseram sensações de desconforto se referem a estes condicionantes. 


\section{Conclusões}

Os voluntários que realizaram os sete percursos pré-definidos, trazem relatos semelhantes sobre suas preferências e sentem-se motivados a frequentar o Parque. Os ambientes com maior predomínio de vegetação natural e com a proximidade da água foram os preferidos e mais representativos nas análises. Ainda, são os locais que instigaram a maiores sensações de conforto e bem-estar.

Os percursos com mais adesão foram os definidos como 1,2 e 5 , onde os elementos naturais são mais representativos. O primeiro percurso traz ainda elementos de identidade do Parque, de sua formação morfológica e cultural e ainda esta conectado com a Avenida Sete de Setembro, com maior circulação e fluxo de pessoas. Esses elementos, reforçam o conceito de topofilia, onde os indivíduos demonstraram os laços afetivos com o ambiente material e seu patriotismo e lealdade com a história de Passo Fundo.

O percurso ainda apresenta diversidade de usos que envolvem áreas mais calmas (para descanso) e também paralelas ao movimento (sinônimos de segurança e dinâmica urbana). As calçadas amplas, limpas, sem barreiras e bem cuidadas proporcionam a todas as pessoas, independente de algum grau de dificuldade em mobilidade, a possibilidade de circular com conforto e eficiência.

O percurso 2 , segundo o relato dos usuários, foi o mais atrativo aos jovens pelas quadras esportivas e pista de skate, apresenta a topografia mais irregular. Enquanto esta é sinônimo de curiosidade, visto que os caminhos vão sendo descobertos conforme são circulados, também gera insegurança em alguns pontos. Entendemos que, para que haja conforto e segurança neste percurso precisa estar em constante movimentação de usuários e ter espaços largos evitando o enclausuramentos em meio a topografia.

Como os desníveis são bem acentuados, a presença da edificação de serviço, constantemente movimentada pelos trabalhadores que fazem a limpeza e manutenção do Parque, auxilia a evitar problemas mais graves de segurança. Ainda, entedemos que este percurso poderia ter um monitoramento mais específico, com câmeras de segurança ou 
circulação de seguranças e guardas, para reduzir o desconforto dos usuários em períodos de menor uso.

O percurso 5, no entorno do lago, recebeu a preferência dos voluntários. Identificamos neste que, a diversidade de locais para sentar, de massa verde (alta e rasteira), a presença de grandes circulações e da mistura de materiais construtivos gera uma união de elementos significativos e importantes aos frequentadores. A presença do lago é destaque por ser elemento contemplativo e convidativo atraindo maior número de pessoas em seu entorno. Atestamos aqui, através dos percursos, que a diversidade e a centralidade são itens fundamentais no espaço público e na vida e dinâmica de um Parque.

Por fim, percebemos através deste estudo que os três percursos mais agradáveis e mais aceitos são aqueles que possuem pontos importantes de referência (nodais ou marcos históricos), vias/calçadas de circulação amplas, bem delimitadas e em boa manutenção, limites territoriais e de funções claros e seguro. O arranjo de dimensões físicas que proporciona a diversidade do ambiente, também é destacado. E é esta diversidade de funções, dimensões e usos (internos e de seu entorno), aliados à boa manutenção, iluminação e melhoria na sensação de segurança, que sustenta a vitalidade do Parque. Os diferentes cenários, com ambientes abertos e amplos permite que os usuários possam escolher onde sentem-se mais atraídos ou mudar, conforme sua vontade ou necessidade.

Considerando que, no espaço urbano os agentes/atores e a dinâmica urbana se alteram constantemente, sejam em partidos arquitetônicos, padrões de edificações, símbolos, significados, reorganização ou modificações de usos, o trabalho revelou que o Parque da Gare é hoje um objeto de extrema importância ambiental, cultural e histórica para a cidade. Confere ainda à Passo Fundo um forte elemento de qualidade da paisagem urbana, focado na diversidade de usos e ambientes atrativos à uma grande diversidade de usuários, requalificando um ambiente abandonado e glorificando a natureza, expressão de políticas públicas e fluxos de investimento de capital aos espaços públicos.

Por fim, o contato direto com os visitantes e a utilização de registro fotográfico como método, aprimorou a pesquisa e servirá de embasamento à futuros estudos, cada vez mais sistemáticos para qualificar a percepção ambiental de espaços abertos e públicos, à partir do cruzamento das análises técnicas e da percepção do usuário. 


\section{Referências bibliográficas}

ALBERTI, M. The effects of urban patterns on ecosystem functioning. International Regional Science Review, 2005. 28(2), 168-192.

AMORIM FILHO, O. B. A evolução do pensamento geográfico e a fenomenologia. Sociedade e Natureza, Uberlândia, n. 21 e 22, p. 67-87, jan/dez. 1999.

AUGÉ, A. Não lugares: introdução a uma antropologia da supermodernidade. Campinas: Papirus, 1994. ISBN 85 308 0291-8.

BARGOS, D. C.; MATIAS, L. F.. Áreas verdes urbanas: um estudo de revisão e proposta conceitual. 2011, v. 6, n. 3, REVSBAU, Piracicaba, p. 172-188.

BERQUE, A.. Paisagem-marca, paisagem matriz: elementos da problemática para uma Geografia cultural. In: CORRÊA, R. L.; ROSENDAHL, Z. (org). Paisagem, tempo e cultura. Rio de Janeiro: EdUERJ, 1998.

BRASIL, IBGE - Instituto Brasileiro de Geografia e Estatística., Censo Demográfico, 2010. Acesso em 08 de jun 2017. Disponível em: http://ibge.gov.br/home/estatistica/populacao/censo2010/.

CERTEAU, M. A invenção do cotidiano. Petrópolis: Vozes, 1996. ISBN 85-326-1669-0.

CLAVAL, Paul. Do olhar do Geográfo a Geografia como Estudo do Olhar dos outros. Conferência Proferida no IV Simpósio Nacional Espaço e Cultura. Rio de Janeiro: UERJ. Outubro de 2014.

CHIESURA, A. (2004). The role of urban parks for the sustainable city. Landscape and Urban Planning. 68. 2004. Disponível em: https://www.sciencedirect.com/science/article/pii/S0169204603001865?via\%3Dihub. ISSN 0169-2046, 129-138.

COOPER, Rachel; BURTON, Elizabeth, COOPER, Cary L.. Wellbeing: A Complete Reference Guide, Volume II, Wellbeing and the Environment. John Wiley \& Sons Itd, 2014. ISBN: 978-1-118-60837-1.

CULLEN, Gordon. Paisagem urbana. 70a ed. Lisboa, 2006. ISBN 978972-44-1401-0.

CVEJIĆ, Rozalija; ELER, Klemen; PINTAR, Marina; ŽELEZNIKAR, Špela; HAASE, Dagmar; KABISCH, Nadja; STROHBACH, Michael (2015) A typology of urban green spaces, ecosystem provisioning services and demands; Green Source, V10 • May 13th.

COSTA, R. et al. Uso, afetividade e percepção: um estudo da satisfação dos frequentadores do Parque do Sabiá em Uberlândia-MG. Revista de Geografia, v. 28, n. 1, p. 14-24, 2011.

DANNA, M. F., \& MATOS, M. A. Aprendendo a observar. São Paulo: EDICON, 2006. ISBN 85-290-0370-5.

GALENDER, F. C. Considerações sobre a conceituação de espaços públicos. Paisagem ambiente: Ensaios, n. 4, p. 113-120, jun. 1992.

GALENDER, F. C. A ideia de sistema de espaços livres públicos na ação de paisagistas pioneiros na América Latina. Paisagens em Debate, n. 3, nov. 2005.

GEHL, J.. Life between buildings: using public space. Washington: Island Press, 2011. ISBN-10: 1597268275

GEHL, J., \& SVARRE, B.. How study public life. Washington: Island Press, 2013. ISBN 13:978-1-61091-423-9.

GERHARDT, Tatiana Engel; SILVEIRA, Denise Tolfo. Métodos de pesquisa. 1o ed. Porto Alegre: Editora UFRGS 2009. ISBN 978-85-386-0071-8. Disponível em: http://www.ufrgs.br/cursopgdr/downloadsSerie/derad005.pdf>.

GRIMM, N. B., \& REDMAN, C. L. (2004). Approaches to the study of urban ecosystems: The case of central Arizona. Phoenix: Urban Ecosystems, 2004. ISSN 1083-8155.

GONÇALVEZ, W. Padrões de assentamento de áreas verdes municipais: uma visão crítica. 1994. 116f. Tese (Doutorado em Arquitetura e Urbanismo) - Faculdade de Arquitetura e Urbanismo, Universidade de São Paulo, São Paulo, 1994. 
HAESBAERT, R. Identidades Territoriais: entre a multiterritorialidade e a reclusão territorial (ou: do hibridismo cultural à essencialização das identidades). In: HAESBAERT, R.; ARAUJO, F. Identidades e Territórios: questões e olhares contemporâneos. Rio de Janeiro: Access, 2007. p. 33-56.

HALBWACHS, M. A memória coletiva. São Paulo: Centauro, 2006. ISBN 85-7115-038-9

HARDT, L. P.. Subsídios à gestão da qualidade da paisagem urbana. Tese (Doutorado em Engenharia Florestal). Curitiba: Universidade Federal do Paraná, 2000.

JACOBS, J.. Morte e vida de grandes cidades. São Paulo: Martins Fontes, 1960. ISBN 978-85-7827-421-4.

KLIASS, R. G. Parques urbanos de São Paulo. São Paulo: Pini Editora, 1993. ISBN 8572660240.

LUCHIARI, M. T. D. P. A (re)significação da paisagem no período contemporâneo. In: ROSENDAHL, Z.; CORRÊA, R. L. Paisagem, imaginário e espaço. 2001: EdUERJ, 2001. p. 9-28. ISBN 9788575110119

LYNCH, K.. Image of the city. Cambridge, MA: MIT Press, 1960. ISBN 0-026-12004-6/0-026-620001-4.

LYNCH, K. A boa forma da cidade. Lisboa: Edições 70, 2012. ISBN 978-972-44-1330-0

MACEDO, S. S.; SAKATA, F. G. Parques urbanos no Brasil. 2. ed. Coleção Quapá. São Paulo: Edusp, 2003. ISBN 85-314-0655-2.

MACHADO, L. P. A Praça da Liberdade na percepção do usuário. Revista Geografia e Ensino, Belo Horizonte, v. 5, n. 1, p. 18-33, 1993.

MELO, Hérica Maria Saraiva: LOPES, Wilza Gomes Reis; SAMPAIO, Dayane Batista. Os Parques Urbanos na História da Cidade: percepção, afetividade, imagem e memória da paisagem. Revista Nacional de Gerenciamento das Cidades, v.05, n.32, 2017. ISSN 2318-8472.

OLIVEIRA, L. A percepção da Qualidade Ambiental. A Ação do Homem na Qualidade Ambiental. Rio Claro: UNESP, 1983.

ONU. World Urbanization Prospects - revision 2014. Published by the United Nations, Department of Economic and Social Affairs. ISBN 978-92-1-151517-6, Copyright (C) United Nations, 2014

POLLACK, M. Memória e Identidade Social. Estudos Históricos, v. 5, n.10, p.200-212, 1992.

ROCHA, L. B.. O centro da cidade de Itabuna. Trajetória, signos e significados. Ilhéus: Ed. UESC, 2003.

RYAN, R. L. Exploring the effects of Environmental Experience on attachment to Urban Natural Areas. Environment and Behavior, USA, v.37, n. 3, p. 1-41, 2005.

ROCHA, L. B. O centro da cidade de Itabuna: trajetória, signos e significados. Ilhéus: Editus, 2003. ISBN 857455-059-0

ROSENDAHL, Z.; CORRÊA, R. L. Paisagem, imaginário e espaço. 2001: EdUERJ, 2001. p. 9-28. ISBN 9788575110119

SANTOS, M.. A natureza do espaço: técnica e tempo, razão e emoção. 4.ed. 3. reimpre. São Paulo: EDUSP,2006. ISBN 85-314-0713-3.

SARTORI, M. G. B. Clima e Percepção Geográfica. Universidade de São Paulo. São Paulo. 2000. ISBN: 978-8566301-23-6

SAUER, C..A morfologia da paisagem. Em R. L. CORRÊA, \& Z. ROSENDAHL, Paisagem, tempo e cultura. Rio de Janeiro: EdUERJ, 1998. P.12-74. ISBN 85-85881-56-9.

SÁ, Teresa. Lugares e não lugares em Marc Augé. Tempo Social - Revista de Sociologia da USP, vol. 26, n. 2, p. 209-229, nov. 2014. Disponível Círculo Fluminense de Estudos Filológicos e Linguísticos 24 Cadernos do CNLF, vol. XX, no 03 - Ensino de língua e literatura. em: . Acesso em: 15- 01-2018.

SCHIER, R. A. Trajetórias do conceito de paisagem na Geografia. Revista R'AEGA, Curitiba, n. 7, p. 79-85, 2003. ISSN 2177-2738.

TARDIN, R. Espaços livres: sistema e projeto territorial. Rio de Janeiro: 7Letras, 2008. ISBN 978-85-7577-552-3.

TUAN, Y.. Topofilia: um estudo da percepção, atitudes e valores do meio ambiente. São Paulo: Difel, 1980.

ISBN-10: 8572166270. 
TZOULAS, K.; KORPELA, K.; VENN, S.; YLI-PELKONEN, V.; KAŹMIERCZAK, A.; NIEMELA, J.; JAMES P.. Promoting ecosystem and human health in urban areas using Green Infrastructure: a literature review. Landscape and Urban Planning, 81, 2007. 167-178. ISSN 0169-2046.

VAM KAMP, Irene; LEIDELMEIJER, Kees; MARSMAN, Gooitske; HOLLANDER, Augustinus de. Urban environmental quality and human well-being Towards a conceptual framework and demarcation of concepts; a literature study. Landscape and Urban Planning 65 (2003) 5-18;

WHYTE, A. V. Guidelines for Fields Studies in Environmental Perception: Technical Notes 5. França: UNESCO, 1997. Disponível em: http://unesdoc.unesco.org/images/0002/000247/024707eo.pdf. Acesso em: junho de 2018. 